\title{
Constraints in Adoption of Improved Cultivation Practices of Black Gram
}

\author{
Seema Jat ${ }^{*}$, K.L. Dangi and Bheru Lal Kumhar \\ Maharana Pratap University of Agriculture and Technology, Udaipur, \\ Agriculture University, Kota, India \\ *Corresponding author
}

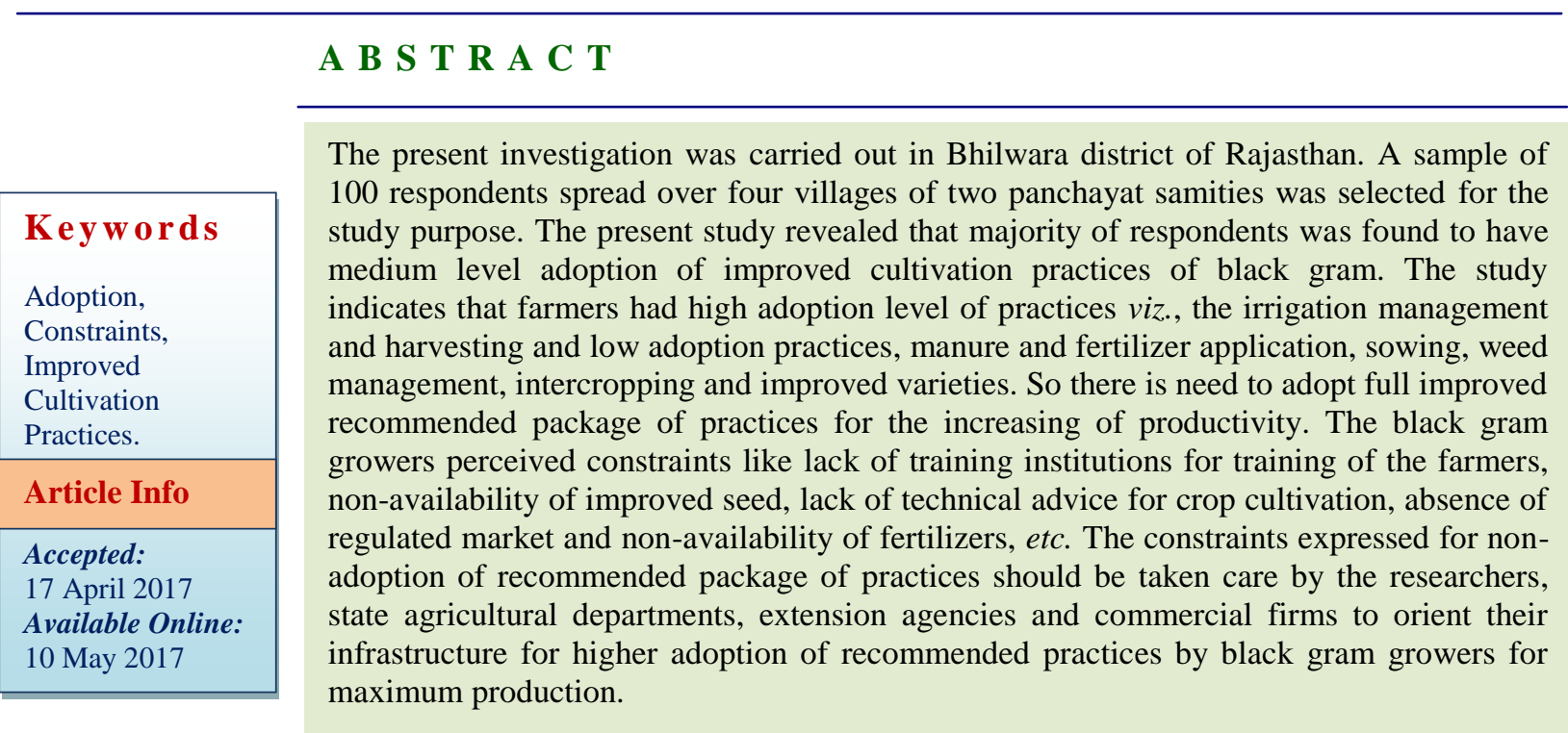

\section{Introduction}

India grows a variety of pulse crop under a wide range of agro-climatic conditions and has a pride of being the world's largest producer of pulses. It is important source of protein especially for vegetarian and is also referred as poor man's meat. The major pulse crops grown in India are black gram, green gram, chickpea, pigeonpea, lentil and fieldpea, in which India produces 70 per cent of worlds' black gram production and accounts for 10 per cent of country's total pulse production (Gowda et al., 2013).

Black gram is also known as Urd or Black lentil. It is one of the most important pulse crops grown throughout the country in very diverse agro-climatic conditions. According to annual report of Ministry of Agriculture, 2014 black gram produces $22.10 \mathrm{Kg}$ of Nitrogen/ha, which is equivalent to 59 thousand tons of urea annually. Furthermore, it helps in fixing atmospheric nitrogen in symbiotic association with the rhizobium bacteria that is present on the root nodules and hence maintains the soil fertility. Black gram supplements the cereal-based diet and contains about 26 per cent vegetable protein, which is three times that of cereals. It is well known that a diet deficient in protein intake can cause Protein Energy Malnutrition. 
The leading states producing black gram in India are Maharashtra, Uttar Pradesh, Andhra Pradesh, Rajasthan, Madhya Pradesh and Karnataka. These states contribute 80 per cent of total pulse production as reported by the Directorate of Economics and Statistics, Department of Agriculture and Cooperation, 2010.

In Rajasthan State black gram is grown in 1, $96 \mathrm{lakh} / \mathrm{ha}$. area with a production of 70,561 tonnes, with average yield of $360 \mathrm{~kg} / \mathrm{ha}$. Bhilwara occupies first position with respect to area 50,089 ha with annual production of 17,111 tonnes and an average yield of 342 $\mathrm{kg} / \mathrm{ha}$. Agriculture is main occupation of majority of the population in the rural area of Bhilwara district. According to the Commissionerate of Agriculture, Govt. of Rajasthan, Jaipur (2013-14) the average yield of black gram is only $360 \mathrm{~kg} / \mathrm{ha}$. as against the recommended average yield of the crop is 15-20 quintals/ha (Panda, 2012). The low production of black gram may be due to the non-adoption or poor adoption of improved cultivation practices of black gram by the farm women and they may be facing some constraints in its adoption at their own farm which may affect adoption of improved cultivation practices of black gram. Hence this is a challenging task for the scientist and farmers. Under such condition it is quite imperative that reasons for the technological gap in black gram should be identified and studied critically in order to face the existing challenge of low productivity. In this context the present study was undertaken to study the adoption of improved cultivation practices of black gram and identify the constraints as perceived by black gram growers.

\section{Materials and Methods}

The study was carried out in Bhilwara district of Rajasthan to know the Adoption of Improved Black Gram Cultivation Practices by Farm Women and to identify the constraint perceived by them in its adoption at their own farm. A sample of 100 black gram growers was selected randomly from 4 villages of two panchayat samities having highest area under black gram cultivation and from each village 25 growers as respondents. The data were calculated with the help of well-structured interview schedule. Respondents were categorized as high, medium and low adoption.

The practice wise adoption of improved cultivation practices of black gram was ranked based on men percent score (MPS) values. The constraints perceived by black gram growers in adoption of improved black gram practices were tabulated based on frequencies and percentage. The mean percent scores were calculated with the help of following formula.

MPS $=\frac{\text { Sum of scores obtained by respondents in an item }}{\text { Maximum obtainable scores }} \times 100$

\section{Results and Discussion}

\section{Adoption of improved black gram cultivation practices}

It is clear from table 1 that the majority of respondents possessed medium level adoption of improved black gram cultivation practices as indicated by the overall mean percent adoption scores (38.41). Data in table 1 reveal that respondents used improved practices of black gram cultivation with respect to suitable soil and land preparation and irrigation management in black gram cultivation was placed at first and second position in the adoption continuum as reflected from (77.12\% and 67\%). Whereas adoption of harvesting practices and manure and fertilizer application was found at third and fourth rank with $(55.62 \%$ and $41.35 \%)$ respectively.

This clearly indicates the need to put more efforts by all the concerned convince the 
farmers about improved cultivation practices of black gram. The results are in conformity with finding of Meena (2010).

\section{Overall mean per cent adoption score - 38.41}

The other practices viz. sowing (31.81\%), weed management $(27.11 \%)$, inter cropping $(21.75 \%)$, improved seed variety $(12.5 \%)$ and plant protection measures $(11.44 \%)$ were ranked at fifth, sixth, seventh, eight and nine respectively.

The overall adoption was concerned, it is evident from table 2 that majority $(53 \%)$ of the respondents were having medium level of adoption of improved cultivation practices of black gram and 42 per cent as well as 5 per cent were found in low and high category, respectively.

\section{Constraints perceived by respondents in} black gram cultivation practices

The constraints perceived by black gram growers were categorized into five parts and data regarding these constraints are presented in table 3. The major constraints perceived by black gram growers were lack of training institutions for training of the farmers about improved cultivation practices, nonavailability of improved seeds and chemical fertilizers, lack of knowledge about rhizobium culture, plant protection measures and technical advice for crop cultivation, absence of regulated market and lower prices at harvesting time.

Table.1 Distribution of respondents according to their adoption of various black gram cultivation practices

\begin{tabular}{|c|l|c|c|}
\hline S. No. & \multicolumn{1}{|c|}{ Aspects } & MPS & RANK \\
\hline 1. & Soil and land preparation & 77.12 & I \\
\hline 2. & Irrigation management & 67.00 & II \\
\hline 3. & Harvesting & 55.62 & III \\
\hline 4. & Manure and fertilizer application & 41.35 & IV \\
\hline 5. & Sowing & 31.81 & V \\
\hline 6. & Weed management & 27.11 & VI \\
\hline 7. & Intercropping & 21.75 & VII \\
\hline 8. & Improved seed variety & 12.5 & VIII \\
\hline 9. & Plant protection measures & 11.44 & IX \\
\hline
\end{tabular}

Table.2 Distribution of respondents according to their overall adoption of improved black gram cultivation practices

$$
\mathrm{n}=\mathbf{1 0 0}
$$

\begin{tabular}{|c|l|c|}
\hline S. No. & \multicolumn{1}{|c|}{ Categories } & f /\% \\
\hline 1. & Low $(>33.33)$ & 42 \\
\hline 2. & Medium (33.34 to 66.67) & 53 \\
\hline 3. & High $(<66.67)$ & 5 \\
\hline
\end{tabular}


Table.3 Constraints perceived by respondents in adoption of improve black gram cultivation practices

\begin{tabular}{|c|c|c|}
\hline $\mathbf{S} \mathbf{N o}$ & Conctroints ford bu rocnonds & s/M \\
\hline \multirow{8}{*}{$\mathbf{A}$} & Economic constraints & \\
\hline & High cost of seeds & 22 \\
\hline & High cost of fertilizers & 60 \\
\hline & Lack of credit facility & 28 \\
\hline & Labor intensive affairs & 57 \\
\hline & High cost of machinery & 15 \\
\hline & High post-harvest losses & 54 \\
\hline & High cost of insecticide and pesticides & 64 \\
\hline \multirow[t]{5}{*}{ B } & Technical constraints & \\
\hline & Poor knowledge about high yielding varieties & 52 \\
\hline & Lack of technical advice for crop cultivation & 82 \\
\hline & Lack of knowledge about rhizobium culture & 34 \\
\hline & Lack of about plant protection measures & 76 \\
\hline \multirow[t]{5}{*}{$\mathbf{C}$} & Production constraints & \\
\hline & Non-availability of improved seed & 90 \\
\hline & Non availability of fertilizers & 78 \\
\hline & Lack of irrigation facility & 8 \\
\hline & Non availability of labor & 80 \\
\hline \multirow[t]{7}{*}{$\mathbf{D}$} & Marketing constraints & \\
\hline & High cost of transportation facilities & 48 \\
\hline & Absence of adequate storage facilities & 43 \\
\hline & Absence of regulated market & 81 \\
\hline & Lower prices at harvesting time & 78 \\
\hline & No processing industry & 75 \\
\hline & Lack of co-operative marketing system & 76 \\
\hline \multirow[t]{5}{*}{$\mathbf{E}$} & General constraints & \\
\hline & Threat from wild and stray animal & 43 \\
\hline & Lack of training institutions for training of the farmers & 100 \\
\hline & Supply of inferior quality inputs by the input dealers & 47 \\
\hline & Problem of grazing animal & 56 \\
\hline
\end{tabular}

The other problems as expressed by a majority of farmers were high cost of fertilizers, seeds, insecticide and pesticides, poor knowledge about high yielding varieties and adequate storage facilities and supply of inferior quality inputs by the input dealers, etc. These finding clearly indicates the need to develop strong research based centers to tackle day to day problems and offer solution to black gram growers. To overcome the marketing constraints, there is need to develop networks of marketing co-operative basis.
The findings are in line with the result of Mane (2012) in their study on "Knowledge and adoption of recommended production technology of green gram." reported that the major constraints faced by the respondents were supply of inferior quality inputs by input dealers and lack of training institutions for training of the farmers.

It may be concluded that a majority of farmers had medium adoption of improved black gram cultivation practices. The adoption was higher in the soil and land 
preparation, irrigation management and harvesting than the other adopted practices of black gram cultivation. On the other hand less adoption was found in intercropping, improved seed variety, plant protection measures, etc. Hence it may be pointed out that it is no use to adopt some of the improved practices only and neglecting some others one. It is necessary to use the complete package of the improved practices of black gram cultivation for reaching maximization in crop yields.

The major constraints perceived by black gram growers were lack of training institutions for training of the farmers about improved cultivation practices, nonavailability of improved seeds and chemical fertilizers, lack of knowledge about rhizobium culture, plant protection measures and technical advice for crop cultivation, absence of regulated market and lower prices at harvesting time, etc. The constraints are appropriately addressed and overcome by providing technical knowledge about improved black gram cultivation practices.

\section{References}

Commissionerate of Agriculture, Rajasthan Jaipur. 2013-14. Rajasthan Krishi retrieved from articles. www.krishi.rajasthan.gov.in Crop Production. Pdf on July $23^{\text {rd }}$, 2014.Pp 45.

Gowda, C.L., Laxmipathi, Srinivasan, S., Gaur, P.M. and Saxena, K.B. 2013. Enhancing the Productivity and
Production of Pulses in India. I. J. Scientific and Re. Publications, 19: 1113.

Ghadge, R.M. 2014. Constraints in Adoption of Improved Technology of Mandarin. Ind. J. Ext. Edu., 50: 90-92.

Khare, A.L., Wakle P.K. and Mankar D.M. 2013. Farmers Knowledge in Improved Cultivation Practices of Gram. Ind. J. App. Res., 10: 1-4.

Mane, S.S. 2012. Knowledge and Adoption of Recommended Production Technology of Green Gram. M.Sc. thesis, Marathwada Agricultural University, Parbhani.

Meena, N.R. 2010. Knowledge and Adoption of Improved Cluster bean Production Technology by the Farmers in Jaipur District of Rajasthan. M.Sc. thesis, Maharana Pratap University of Agriculture and Technology, Udaipur.

Ministry of Agriculture. 2014. As per the latest reports of sowing of kharif pulses, sowing area has reached 44.47 lakh hectares. Int. J. Inno. Res. Sci., 3: 2319-8753.

Panda S.C. 2012. Crop Production and Management. The Hand Book of Agriculture, pp 349-350.

Raj, A.D., Yadav, V. and Rathod, J.H. 2013. Impact of Front Line Demonstrations (FLD) On the Yield of Pulses. I. J. Scientific Res. Publications, 3: 1-3.

Singh, B. 2010 Adoption of Mungbean Production Technology in Arid Zone of Rajasthan. Ind. Re. J. Ext. Edu., 10: 113.

\section{How to cite this article:}

Seema Jat, K.L. Dangi and Bheru Lal Kumhar. 2017. Constraints in Adoption of Improved Cultivation Practices of Black Gram. Int.J.Curr.Microbiol.App.Sci. 6(5): 1820-1824. doi: https://doi.org/10.20546/ijcmas.2017.605.198 